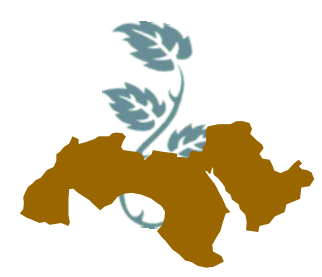

Arab Univ.

J. Agric. Sci., Ain Shams Univ., Cairo, 26(1), 337-347, 2018

\title{
EVALUATION OF SOME CHENOPODIUM QUINOA CULTIVARS UNDER SALINE SOIL CONDITIONS IN EGYPT
}

\author{
Ebrahim ${ }^{1}$, M.E.A.; S.A. Hussin ${ }^{1}$; A.A. Abdel-Ati ${ }^{3}$; S.H. Ali $^{2}$ and S.S. Eisa ${ }^{1}$ \\ 1- Agric. Botany Dept., Fac. of Agric., Ain Shams Univ., Cairo, Egypt \\ 2- Agric. Biochemistry Dept., Fac. of Agric., Ain Shams Univ., Cairo, Egypt \\ 3- Ecology and Dry Land Agriculture Division Plant Production Dept., Desert Research Center, \\ Cairo, Egypt
}

Keywords: Chenopodium quinoa, Saline soil, Protein and fiber \%, Seed yield, Seeds quality

\section{ABSTRACT}

This study aimed to evaluate seed yield, morphological variability and nutritional quality for two cultivars of Chenopodium quinoa under high saline soil conditions $\left(E_{\mathrm{e}} 22 \mathrm{dSm}^{-1}\right)$ in Egyptian Northeastern coast. Responses to salinity were greatly differed between the two cultivars. The Peruvian cultivar CICA produced seed yield significantly higher than Bolivian cultivar Real. CICA cultivar also showed significant high performances for most of morphological traits. Among the 10 morphological traits, leaves dry weight, shoot fresh weight and leaves fresh weight showed significant positive association with seed yield. No significant difference has been found between both cultivars for most seed quality traits except for the concentration of crude protein and crude fiber in seeds were significantly higher in CICA cultivar. Although CICA cultivar exhibited significantly higher sodium concentration in the leaves than that found in the leaves of Real cultivar, but it was much more efficient in restricting sodium uploading into seed. These results revealed that the Peruvian cultivar CICA seems to be adaptable and more suited to dry-saline soil in Northeastern coastal region of Egypt, as it gave considerable high seed yield with better quality in terms of high protein and fiber percentage and low $\mathrm{Na}$ concentration in seeds.

\section{INTRODUCTION}

Soil salinity is one of the major deleterious environmental stresses limiting agricultural production worldwide. Salinity in irrigated lands increased over the last 20 years due to poor irrigation management, and is predicted to become more pronounced in near future due to climate changes (Nguyen, 2016). This situation is becoming more worse in arid and semi-arid regions due to intensive use of precious fresh water as a result of increased in irrigation requirements, under high evapotranspiration conditions and this inevitably leads to accelerates the secondary salinization (Munns, 2005). Nowadays in arid and semi-arid region, the utilizing of saline water and/or saline soil in agriculture has appeared as imperative options (Hirich et al 2014). However, the most of the world's major food crops species are salt sensitive (glycophytes) and can cope only with a very limited concentrations of salt in their growth media. A soil or water is considered to be saline when the electric conductivity reaches $4 \mathrm{dSm}^{-1}$, and that significantly reducing the yields of most conventional crops (Munns \& Tester, 2008 and Panta et al 2014). In spite of the intensive research has been conducted to increase salt tolerance in conventional crops, using classical breeding or genetic manipulation methods, but because of salt tolerance is a complex trait in plants, the outcome have met limited success so far (Flowers, 2004). On the other hand, management practices to reduce salt concentrations in soil or irrigation water are often expensive and cannot always be applied in developing countries (Djanaguiraman et al 2006). An alternative approach to deal with the salinity problem is utilizing salt tolerant plants for sustainable food production. Chenopodium quinoa Willd. is a facultative halophyte and could be used as a promising alternative cash crop for land and water unsuitable for conventional crops in arid and semiarid regions (Eisa et al 2005). During the recent 
time, quinoa attracted worldwide attention because of its extraordinary tolerance to various unfavorable environmental conditions (Choukr-Allah et al 2016). Quinoa has the ability to grow and produce seeds under high salinity levels similar to those found in sea-water (Koyro et al 2008; Hariadi et al 2011; Shabala et al 2013; Panuccio et al 2014 and Eisa et al 2017). In addition, quinoa seed is known for its high nutritional value because of its unusual composition and exceptional balance between protein and crude fat. It is an excellent example of 'functional food' that aims at lowering the risk of various diseases (Vega-Gálvez et al 2010). Quinoa seed is among the most important grain crops, in terms of its high quantity and quality of protein, whereas its seed has a high content of the essential amino acids, such as threonine, lysine and methionine. Also, quinoa seed is a rich source of nutritional elements and vitamins, and it has been found to contain compounds like polyphenols, flavonoids, and phytosterols with possible extra health benefits (Abugoch James, 2009). For these reasons, global demand for quinoa consumption has increased and its cultivation has spread around the world in last decades. In spite of quinoa is a highly salt tolerant species, but it exhibited a considerable intraspecific genetic variability in tolerance levels (Ruiz et al 2016). Therefore, basic research on morphological responses and physiological mechanisms of salt stress on plants has a paramount importance for selection of the best suitable genotypes (Shabala et al 2013). This knowledge may therefore be useful to understand of salt tolerance traits and can facilitate the selection of the suitable cultivar with high capability of resistance and economical potential yield under saline condition (Adolf et al 2012).

The variability of the morphological, yield and seed quality traits may be a good opportunity for elucidating key of salt tolerance mechanisms through the comparison of various cultivars with different capability of resistance under saline stress. Therefore, the objective of the present work was to evaluate the different capability of two cultivars (CICA and real) of quinoa under dry-saline coastal regions in Egypt.

\section{MATERIALS AND METHODS}

Two field experiments were conducted in Sahl El-tina plain located in northwestern part of Sinai (latitude $32^{\circ} 27^{\prime} 50^{\prime \prime}$ and longitude $30^{\circ}$ 59' 47") during the growing seasons 2013 and 2014 to evaluate the response of two cultivars of quinoa, namely
Chenopodium quinoa willd. cv. CICA and Chenopodium quinoa willd. cv. Real. The location was characterized by high saline soil (Ece $20 \mathrm{dSm}^{-1}$ ), and the electrical conductivity of irrigation water $1.6 \mathrm{dSm}^{-1}$.

\section{Location preparation}

Soil in location was prepared for cultivation by land plough and ridges construction. Compost with a rate of $4 \mathrm{t}$ fed. and phosphorus at a rate of $50 \mathrm{~kg}$ $\mathrm{P}_{2} \mathrm{O}_{5}$ fed. were added during the final preparation of land and thoroughly mixed with the soil. Nitrogen was added as side dressing at a rate of $89 \mathrm{~kg}$ $\mathrm{N}$ fed. in two equal doses after 30 and 51 days from sowing date. Potassium was added at a rate of $55 \mathrm{~kg} \mathrm{~K} \mathrm{~K}_{2} \mathrm{O}$ fed. at flowering stage. Quinoa grains were sown on the second week of October, and they were harvested on the second week of February for CICA cultivar and the second week of January for Real cultivar in both. About $8-10$ seeds per hill were sown at a density of 30000 plants per fed. A complete randomized design with six experimental plots (replicates), each with an average area of $16 \mathrm{~m}^{2}$ was used. After 3 weeks of sowing date, plants were thinned to one plant per hill and crop practice managements were regularly carried out.

\section{Growth parameters}

A random sample of 5 quinoa plants from two quinoa cultivars were taken from each experimental plot after 60 days of sowing date to determine the growth parameters (i.e. plant height, main inflorescence length, number of leaves/plant, shoot fresh weight, shoot dry weight, stem diameter, leaf area, leaves fresh weight, leaves dry weight, main inflorescence weight, sub inflorescences weight, number of sub inflorescences, mean length sub inflorescences).

\section{Yield of quinoa varieties}

At 120 days for CICA cultivar and 90 days for Real cultivar, quinoa plant samples from one square meter of the central rows in each plot were randomly taken by cutting at ground level, then plant samples were lift to air-dried for at least 4 days. After that, dried plant samples were threshed and winnowed by hand. Yield parameters of seed yield (kg/fed.), weight of 1000 seed $(\mathrm{g})$, seed percentage per panicle were determined. 


\section{Biochemical analysis}

Grain samples were dried in an oven at $65^{\circ} \mathrm{C}$ till constant weight then ground in stainless-steel mill and kept until biochemical analysis. A definite weights of seed dried samples were wet digested as described by (Wolf, 1982) to determine total $\mathrm{N}$ \& $\mathrm{Na}$. Total $\mathrm{N}$ in quinoa seeds was determined using micro-kjeldahl method according to Chapman and Pratt (1982). Total protein percentage was calculated using the following equation: protein $\%=$ total $\mathrm{N} \times 6.25$. While, sodium percentage was measured using flame photometer method (JENWAY, PFP-7, ELE Instrument Co. Ltd., UK) as described by Cottenie et al (1982). Moisture \%, ash percentage, crude fat, crude fiber and total carbohydrates, were determined according to the methods described in (AOAC, 1995).

\section{Statistical analysis}

All data sets were tabulated and subjected to statistical analysis using (SAS) User's Guide, (1998).

\section{RESULTS}

\section{Variability studies}

The values for different morphological, chemical yield and seed quality traits are presented in Tables (1 \& 2). CICA cultivar gave seed yield significantly higher than that of Real cultivar. CICA cultivar also exhibited high values for most morphological traits except mean of leaf area. In this regard, an important aspect should be taken into account that is the lack of secondary branches in Bolivian cultivar Real, on the contrary the Peruvian cultivar CICA characterized by producing secondary branches (Table 1). This is may be an explanation for the increasing the mean of leaf area per plant in Real over that found in CICA. Regarding the seed yield, CICA cultivar showed significant higher values for seed percentage per panicle and harvest index but was low in weight of 1000 seeds as compared to Real cultivar. Among all quality traits, concentrations of protein and fiber in seeds were significantly higher in CICA than Real (Table 2). In spite of increasing sodium concentration in the leaves of CICA cultivar over that found in Real but the seeds of Real had accumulated much higher sodium concentration than that found in CICA (Tables 1\&2).

Results illustrated in Fig. (1) indicates that ratio of leaf area $\left(\mathrm{cm}^{2}\right)$ related to Real variety was 1.5 superior than CICA (0.64). On the other hand, CI$\mathrm{CA}$ was superior in all other characters of growth parameters. The lower value of ratio was 1.13 recorded to main inflorescence, while the higher ratio recorded to leaf dry weight (3.25) threefold as compared to Real. That's mean CICA was the promising seed has adapted characteristic to grow well under saline condition in Egypt rather than Real. In contrary, Real was more promising if it sowing as a trap for photosynthesis utilizes due to the higher ratio 1.5 and short time to harvest $(60$ days). In addition CICA was promising in dry matter, if the farmer need dry weight, CICA is the best one.

\section{Correlation studies}

The correlation coefficients among various traits are presented in Tables (3-1, 3-2). All morphological traits except the length of main inflorescence showed positive association with seed yield, the highest correlation value was recorded for shoot fresh weight followed by shoot dry weight (0.96 and 0.94 , respectively). Also, plant height and stem diameter showed highly significant correlation with seed yield. An interesting observation was appeared with regard to association between $\mathrm{Na}$ concentration in leaves and seed yield, which was positive and highly significant, correlated. Concerning seed yield traits, seed percentage per main panicle presented a positive and significant correlation with seed yield. Meanwhile, the weight of 1000 seed has a negative and highly significant correlation with seed yield. Among the seed quality traits, crude protein and crude fiber exhibited positive significant correlation with seed yield, but a negative significant correlation has been recorded between the concentration of $\mathrm{Na}$ in seed and seed yield. 
Table 1. Mean performance of two cultivars for morphological, chemical and yield traits in Chenopodium quinoa

\begin{tabular}{|c|c|c|c|c|c|c|}
\hline $\begin{array}{l}\text { Morphological, } \\
\text { chemical and yield traits }\end{array}$ & CICA cultivar & Real cultivar & Mean & $P \geq 0.05$ & $P \geq 0.01$ & CV \\
\hline Plant height $(\mathrm{cm})$ & $60.3 \pm 0.5$ & $49.3 \pm 3.2$ & $55.0 \pm 2.6$ & 5.23 & 8.68 & 11.6 \\
\hline $\begin{array}{l}\text { Main inflorescence length } \\
(\mathrm{cm})\end{array}$ & $18 \pm 1.0$ & $16 \pm 3.6$ & $17.0 \pm 1.1$ & 5.99 & 9.95 & 15.34 \\
\hline Number of leaves/plant & $142 \pm 15.3$ & $52 \pm 13.7$ & $97.0 \pm 20.1$ & 32.88 & 54.52 & 52.1 \\
\hline $\begin{array}{l}\text { Shoot fresh weight (g } \\
\left.\text { plant }^{-1}\right)\end{array}$ & $134.1 \pm 2.1$ & $43.0 \pm 13.5$ & $88.6 \pm 20.6$ & 21.87 & 36.27 & 57.2 \\
\hline $\begin{array}{l}\text { Shoot dry weight } \\
\quad\left(\text { g plant }^{-1}\right)\end{array}$ & $35.5 \pm 0.5$ & $15.7 \pm 4.9$ & $25.6 \pm 4.6$ & 7.91 & 13.12 & 44.3 \\
\hline Stem diameter $(\mathrm{mm})$ & $9.0 \pm 0.0$ & $6 \pm 1.0$ & $7.5 \pm 0.7$ & 1.60 & 2.66 & 23.5 \\
\hline Mean leaf area $\left(\mathrm{cm}^{2}\right)$ & $7.5 \pm 1.3$ & $11.7 \pm 1.1$ & $9.6 \pm 1.0$ & 2.73 & 4.53 & 26.6 \\
\hline $\begin{array}{l}\text { Leaves fresh weight ( } \mathrm{g} \\
\text { plant }^{-1} \text { ) }\end{array}$ & $22.5 \pm 3.0$ & $7.3 \pm 1.5$ & $14.9 \pm 3.5$ & 5.31 & 8.81 & 57.3 \\
\hline $\begin{array}{l}\text { Leaves dry weight ( } g \\
\text { plant }^{-1} \text { ) }\end{array}$ & $3.6 \pm 0.5$ & $1.1 \pm 0.2$ & $2.4 \pm 0.5$ & 0.86 & 1.44 & 59.8 \\
\hline $\begin{array}{c}\text { Main inflorescence weight } \\
\left({\left.\text { ( } \text { plant }^{-1}\right)}^{-1}\right.\end{array}$ & $36.2 \pm 7.6$ & $16.6 \pm 5.5$ & $26.4 \pm 5.0$ & 14.94 & 24.79 & 46.5 \\
\hline $\begin{array}{c}\text { sub inflorescences weight } \\
\left(\mathrm{g} \mathrm{plant}^{-1}\right)\end{array}$ & 51.82 & 0.0 & $25.9 \pm 11.7$ & 10.64 & 17.65 & 110.73 \\
\hline $\begin{array}{l}\text { Number of sub } \\
\text { inflorescences }\end{array}$ & 18.0 & 0.0 & $9.0 \pm 4.06$ & 3.2 & 5.32 & 110.44 \\
\hline $\begin{array}{l}\text { Mean length sub } \\
\text { inflorescences }\end{array}$ & 4.7 & 0.0 & $2.3 \pm 1.09$ & 1.85 & 3.06 & 113.92 \\
\hline $\begin{array}{l}\text { Na Concentration in } \\
\text { leaves }(\mathrm{mg} / \mathrm{kg})\end{array}$ & $656.7 \pm 0.0$ & $459.0 \pm 0.04$ & $557.8 \pm 44.3$ & 19.4 & 32.16 & 19.5 \\
\hline Seed Yield kg fed ${ }^{-1}$ & $1910 \pm 96.4$ & $177 \pm 11.0$ & $1044 \pm 50.5$ & 155 & 257 & 91 \\
\hline 1000 seed weight $(\mathrm{g})$ & $4.0 \pm 0.0$ & $5.8 \pm 0.5$ & $4.9 \pm 0.43$ & 0.84 & 1.41 & 21.2 \\
\hline $\begin{array}{l}\text { Seed percentage per } \\
\text { panicle (\%) }\end{array}$ & $75.0 \pm 2.9$ & $63.7 \pm 5.7$ & $69.3 \pm 3.0$ & 10.27 & 17.03 & 10.7 \\
\hline Harvest index & $0.34 \pm 0.02$ & $0.13 \pm 0.02$ & $0.24 \pm 0.05$ & 0.05 & 0.086 & 48.2 \\
\hline
\end{tabular}

CV: coefficient of variability 
Table 2. Mean performance of two cultivars for 7 quality traits in Chenopodium quinoa seeds

\begin{tabular}{|c|c|c|c|c|c|c|}
\hline Quality traits & CICA cultivar & Real cultivar & $\begin{array}{c}\text { Mean } \\
\mathbf{\pm} \text { S.E. }\end{array}$ & $\mathbf{P} \geq \mathbf{0 . 0 5}$ & $\mathbf{P} \geq \mathbf{0 . 0 1}$ & $\mathbf{C V}$ \\
\hline Moisture (\%) & $7.2 \pm 0.77$ & $7.6 \pm 0.08$ & $7.4 \pm 0.21$ & 1.23 & 2.05 & 7.1 \\
Crude Proteins (\%) & $13.6 \pm 0.19$ & $12.80 \pm 0.13$ & $13.2 \pm 0.18$ & 0.36 & 0.61 & 3.4 \\
Ash (\%) & $6.41 \pm 0.88$ & $5.63 \pm 0.19$ & $6.02 \pm 0.29$ & 1.44 & 2.38 & 11.8 \\
Fat (\%) & $6.76 \pm 1.14$ & $5.74 \pm 0.99$ & $6.3 \pm 0.45$ & 2.41 & 4.01 & 17.7 \\
Crude Fiber (\%) & $4.41 \pm 0.35$ & $3.29 \pm 0.34$ & $3.9 \pm 0.28$ & 0.78 & 1.29 & 17.8 \\
Carbohydrate (\%) & $61.6 \pm 1.14$ & $65 \pm 0.68$ & $63.3 \pm 0.82$ & 2.13 & 3.53 & 3.2 \\
Na mg kg-1 & $132.5 \pm 6.36$ & $270.5 \pm 17.67$ & $201 \pm 39.9$ & 57.16 & 131.84 & 39.72 \\
\hline
\end{tabular}

CV: coefficient of variability

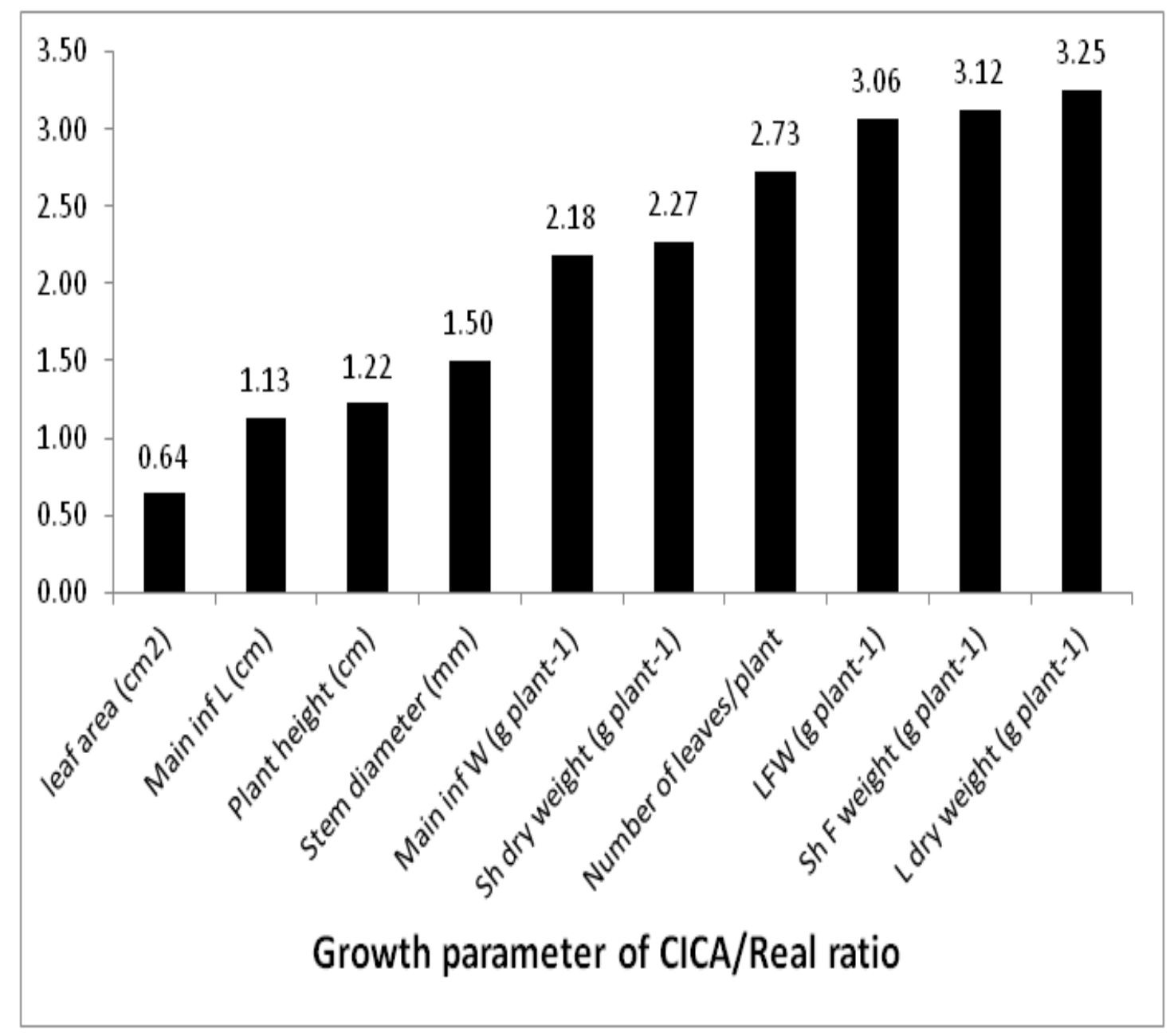

Fig. 1. Ratio of growth parameter of CICA/Real quinoa varieties 


\section{DISCUSSION}

Sustainable agriculture of quinoa on saline soil presupposes initially the exact knowledge of salt tolerance traits in order to facilitate the selection of the suitable cultivar with high capability of resistance and economical potential yield under saline condition. our results showed that both tested cultivars were successfully grown and produced seed yield under high salinity in soil equal to $44 \%$ of that present in sea water level. However, higher seed yield along with better performance for most morphological and quality traits was recorded by CICA cultivar versus Real cultivar. This clearly reflects high adaptability of Peruvian cultivar CICA to coastal saline area of Egypt.

In our results, among all the morphological traits, the number of sub inflorescence, sub inflorescence weight and mean length of sub inflorescence exhibited values of coefficient variance over 100 and that because of the lack of secondary branches in Real cultivar. While the other morphological traits, which are comparable between the two cultivars, leaves dry weight, shoot fresh weight and number of leaves per plant showed the higher values for coefficient of variability. This may be indicates that cultivar with the large number of secondary branches tends to gain high biomass in terms of more leaves per plant and higher shoot fresh weight. On the other hand, shoot fresh weight and number of leaves per plant also correlated positively with plant height and that reflected ultimately on seed yield, similar trend was reported by Rojas et al (2013) and Bhargava et al 2007). The accumulation of biomass and dividing up to reproductive sinks are main determinants of crop yield (Andrade et al 1999). However, the productive capacity for any crop depends on its photosynthetic efficiency and on the effective uploading into the part of potential yield, which is estimated as harvest index. However, harvest index for quinoa cultivars ranged from 0.06 to 0.8 , with a maximum difference of around 15 times (Rojas et al 2003). The harvest index in our present work is located within this range, recorded 0.34 for CICA cultivar and 0.13 for Real cultivar. Therefore, the harvest index of the present study clearly point towards higher efficiency of reproductive partitioning in quinoa cultivar CICA than Real under arid agroclimate Egyptian condition.

Concerning $\mathrm{Na}$ concentration in the leaves of quinoa, our present results showed a significantly higher accumulation of $\mathrm{Na}$ in the leaves of CICA cultivar than that in the leaves of Real cultivar. This might be due to that CICA had significant greater biomass than Real, and it could be therefore absorb more $\mathrm{Na}$ ions. Another explanation has been reported by (Cuin et al 2012) who attributed the differences in $\mathrm{Na}$ accumulation among quinoa varieties to genotype differences. However, the redistribution of $\mathrm{Na}$ from the leaves into seed is an important factor to assess the quality of the seeds, especially produced from the saline soil. Our results clearly indicated that CICA was much more efficient in restricting sodium uploading into seed. Among all seed quality traits only the concentrations of protein and fiber in seeds were significantly higher in CICA than Real. However, in the present work the protein percentage in quinoa seed produced under high saline conditions recorded $13.5 \%$ for CICA cultivar and $12.8 \%$ for Real, and these percentages are almost high in comparison to most of cereals. Soil salinity did not influence on protein content of Peruvian cultivar Hualhuas (Eisa et al 2017). Also, (Wu et al 2016) reported that increasing $\mathrm{NaCl}$ concentrations up to $32 \mathrm{dS} \mathrm{m}^{-1}$ did not alter protein content in quinoa seeds. The high protein in seed of quinoa indicates its high potential as a promising cash halophyte crop in marginal regions where the poverty is hand to hand with malnutrition.

\section{CONCLUSION}

In the light of previously presented data it could be concluded that CICA cultivar was superior than Real cultivar whereas it recorded the vigorous plant growth parameters under saline condition. CICA cultivar exhibit significantly higher performance for most of investigated morphological parameter than Real cultivar. Among seed quality traits, Only the percentage of crude protein and crude fiber showed significant difference. They were higher in CICA cultivar than Real cultivar. Furthermore Peruvian cultivar CICA is more efficient in restricting sodium uploading into seed. Generally it could be demonstrated that CICA cultivar seems to be well adapted for dry saline soil in Northeastern coastal region of Egypt. Where it gave considerable high yield with better quality.

\section{Acknowledgements}

This research is supported by an agricultural target research project "Quinoa as a new nontraditional crop in Egypt, ID-2552" funded by Science \& Technology Development Fund (STDF), Academy of Scientific Research and Technology (ASRT), Ministry of Higher Education \& Scientific Research, Egypt. 


\section{REFERENCES}

Abugoch James, L.E. 2009. Quinoa (Chenopodium quinoa Willd.): Composition, chemistry, nutritional, and functional properties. Adv. Food Nutr. Res., 58, 1-31.

Adolf, V.I., Shabala, S., Andersen, M.N., Razzaghi, F. and Jacobsen, S.E. 2012. Varietal differences of quinoa's tolerance to saline conditions. Plant Soil. 357(1-2), 117-129.

Andrade, F.H., Vega, C.R.C., Uhart, S.A., Cirilo, A.G., Cantarero, M. and Valentinuz, O. 1999. Kernal number determination in maize. Crop Sci., 39, 453-459.

AOAC. 1995. Official Methods of Analysis of AOAC International. $16^{\text {th }}$ ed. Arlington, VA, USA. pp. 69-90.

Bhargava, A., Shukla, S. and Ohri, D. 2007. Genetic variability and interrelationship among various morphological and quality traits in quinoa (Chenopodium quinoa Willd.). Field Crops Research, 101, 104-116

Chapman, H.D. and Pratt, P.F. 1982 Methods of plant analysis, I. Methods of anaylsis for soil, plant and water. Chapman Publishers Riverside California, USA. pp. 60-193

Choukr-Allah, R., Rao, N.K., Hirich, A., Shahid, M., Alshankiti, A., Toderich, K., Gill, S. and Butt, K.R. 2016. Quinoa for marginal environments toward future food and nutritional security in Mena and central Asia regions. Front. Plant Sci., 7(346), 1-11.

Cottenie, A.M., Verloo, L. Kiekens, G. Velgh and Camerlynck, R. 1982. Chemical Analysis of Plants and Soils. pp. 44-45. State Univ. Ghent Belgium, 63.

Cuin, T.A., Zhou, M., Parsons, D. and Shabala, S. 2012. Genetic behavior of physiological traits conferring cytosolic $\mathrm{K}^{+} / \mathrm{Na}^{+}$homoeostasis in wheat. Plant Biol., 14, 438-446.

Djanaguiraman, M., Sheeba, J.A., Shanker, A.K., Devi, D.D. and Bangarusamy, U. 2006. Rice can acclimate to lethal level of salinity by pretreatment with sublethal level of salinity through osmotic adjustment. Plant Soil, 284, 363-373.

Eisa, S., Koyro, H.W., Kogel, K.H. and Imani, J. 2005. Induction of somatic embryogenesis in cultured cells of Chenopodium quinoa. Plant Cell, Tissue and Organ Culture, 81, 243-246.

Eisa, S., Eid, M.A., Abd El-Samad, E.H., Hussin, S.A., Abdel-Ati, A.A., El-Bordeny, N.E., Ali, S.H., Al-Sayed, Hanan M.A., Lotfy, M.E., Masoud, A.M., El-Naggar, A.M. and Ebrahim, M. 2017. Chenopodium quinoa Willd.
A new cash crop halophyte for saline regions of Egypt. Australian Journal of Crop Science, 11, 343-351.

Flowers, T.J. 2004. Improving crop salt tolerance. J. Exp. Bot., 55, 307-319.

Hariadi, Y., Marandon, K., Tian, Y., Jacobsen, S.E. and Shabala, S. 2011. Ionic and osmotic relations in quinoa (Chenopodium quinoa Willd.) plant grown at various salinity levels. J. Exp. Bot., 62, 185 -193.

Hirich, A., Choukr-Allah, R. and Jacobsen, S.E. 2014. Deficit irrigation and organic compost improve growth and yield of quinoa and pea. J. Agro. Crop Sci., 200, 390-398.

Koyro, H.W., Lieth, H. and Eisa, S.S. 2008. Salt tolerance of Chenopodium quinoa Willd. In Leith H, Sucre, M.G., Herzog, B. (Eds.), Mangroves and halophytes: restoration and utilization. Springer, Dordrech, the Netherlands, pp. 133-145.

Munns, R. 2005. Genes and salt tolerance: bringing them together. New Phytologist, 167, 645-663.

Munns, R. and Tester, M. 2008. Mechanisms of salinity tolerance. Annu. Rev. Plant Biol., 59, 651-681.

Nguyen, V.L. 2016. Effect of salinity stress on growth and yield of (chenopodium quinoa Willd) at flower initiation stages. Vietnam J. Agric. Sci., 14, 321-327.

Panta, S., Flowers, T., Lane, P., Doyle, R., Haros, G. and Shabala, S. 2014. Halophyte agriculture: Success stories. Env. Exp. Bot., 107, 71-83.

Panuccio, M.R., Jacobsen, S.E., Akhtar, S.S. and Musscolo, A. 2014. Effect of saline water on seed germination and early seedling growth of halophyte quinoa. Aob Plants, 6, 1-18.

Rojas, C., Pino, J., Basnou, C. and Vivanco, M. 2013. Assessing land-use and -cover changes in relation to geographic factors and urban planning in the metropolitan area of Concepción (Chile). Implications for biodiversity conservation. Applied Geography, 39, 93 -103.

Rojas, W., Barriga, P. and Figueroa, H. 2003. Multivariate analysis of genetic diversity of Bolivian quinoa germplasm. Food Rev. Int., 19, 9 $-23$.

Ruiz, K.B., Aloisi, I., Delduca, S., Canelo, V., Torrigiani, P., Silva, H. and Biondi, S. 2016. Salares versus coastal ecotypes of quinoa: Salinity responses in Chilean landraces from contrasting habitats. Plant Physiol. Biochem., 101, 1-13. 
SAS 1998. SAS User's Guide, ed. SAS Institute Inc. Cary, NC, USA.

Shabala, S., Hariadi, Y. and Jacobsen, S.E. 2013. Genotypic difference in salinity tolerance in quinoa is determined by differential control of xylem $\mathrm{Na}^{+}$loading and stomatal density. J. Plant Physiol., 17, 906 -914.

Vega-Gálvez, A., Miranda, M., Vergara, J., Uribe, E., Puente, L. and Martínez, E.A. 2010. Nutrition facts and functional potential of quinoa
(Chenopodium quinoa Willd.), an ancient Andean grain: a review. J. Sci. Food Agric., 90, 2541-2547.

Wolf, B. 1982. A comprehensive system of leaf analysis and its use for diagnosing crop nutrients status. Comm Soil Sci Plant Analysis. 13, $1035-1059$.

Wu, G., Peterson, A.J., Morris, C.F. and Murphy, K.M. 2016. Quinoa seed quality response to sodium chloride and sodium sulfate salinity. Front. Plant Sci., 7(790), 1-8. 